\title{
Oak Ridge Research Reactor Quarterly Report April, May, and June of 1976
}
S. S. Hurt, III
E. D. Lance 


\section{DISCLAIMER}

This report was prepared as an account of work sponsored by an agency of the United States Government. Neither the United States Government nor any agency Thereof, nor any of their employees, makes any warranty, express or implied, or assumes any legal liability or responsibility for the accuracy, completeness, or usefulness of any information, apparatus, product, or process disclosed, or represents that its use would not infringe privately owned rights. Reference herein to any specific commercial product, process, or service by trade name, trademark, manufacturer, or otherwise does not necessarily constitute or imply its endorsement, recommendation, or favoring by the United States Government or any agency thereof. The views and opinions of authors expressed herein do not necessarily state or reflect those of the United States Government or any agency thereof. 


\section{DISCLAIMER}

Portions of this document may be illegible in electronic image products. Images are produced from the best available original document. 
Printed in the United States of America: Available from National Technical Informatiun Service

U.S. Department of Commerce

5285 Port Royal Road, Springfield, Virginia 22161

Price: Printed Copy $\$ 4.00$; Microfiche $\$ 2.25$

This report was prepared as an account of work sponsored by the United States Government. Neither the United States nor the Energy Research and Development Administration/United States Nuclear Regulatory Commission, nor any of their employees, nor any of their contractors, subcontractors, or their employees, makes any warranty, express or implied, or assumes any legal liability or responsibility for the accuracy, completeness or usefulness of any information, apparatus, product or process disclosed, or represents that its use would not infringe privately owned rights. 
Contract No. W-7405-eng-26

OPERATIONS DIVISION

OAK RIDGE RESEARCH REACTOR QUAR'LERLY REPORT

APRIL, MAY, AND JUNE OF 1976

S. S. Hurt, III

E. D. Lance

Date Published: November 1976

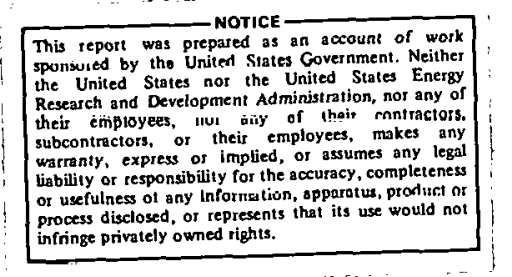

NOTICE This document contains information of a preliminary nature and was prepared primarlly for internal use at the Oak Ridge National Laboratory. It is subjett to revision or eorroction and therafare dnes not represent a final report.

OAK RIDGE NATIONAI LABORATORY

Oak Ridge, Tennessee 37830

operated by

UNION CARBIDE CORPORATION

for the

ENERGY RESEARCH AND DEVELOPMENT ADMTNISTRATION 


\section{THIS PAGE}

\section{WAS INTENTIONALLY LEFT BLANK}




\section{CONTENTS}

\section{Page}

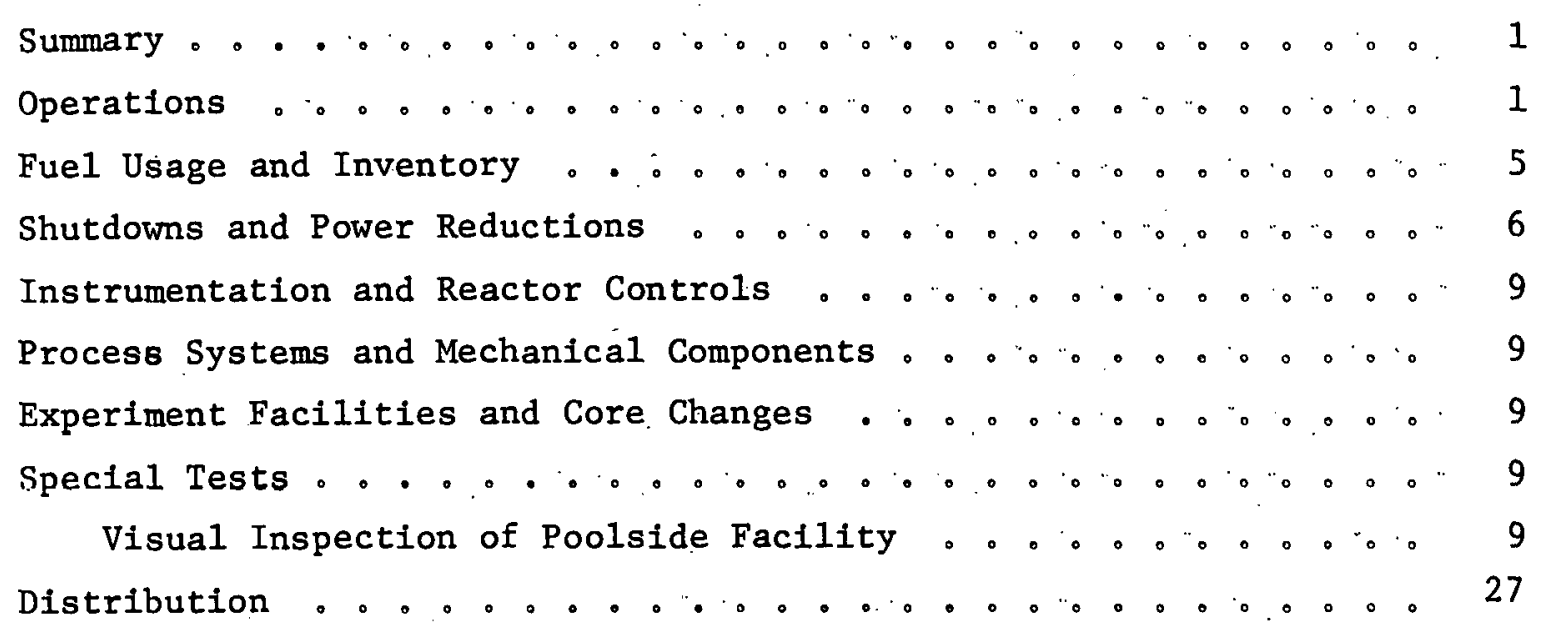




\section{SUMMARY}

The ORR operated at an average power level of 29.7 MN for: $90 \%$ of the time during Apri1, May, and June of 1976. Twenty-five fuel elements were declared spent ( $52.3 \%$ average burnup) during the quarter, while twenty-five new elements were placed in service... Two shim-rod elements were retired from-service at an average burnup of $62.5 \%$.

The reactor was shut down on thirteen occásions, four of which were unscheduled. One end-of-cycle shutdown accourted for $61.1 \%$ of the total downtime.. The remaining downtime: was used principally for refueling and experiment work:

Maintenance activities, both mechanical and instrument, were essentially routine in nature.

A special test completed during the quarter was the visual inspection of the poolside factilty.

\section{OPERATIONSS}

The basic operating data presented in Table 1 indicates that the ORR operation for the quarter was normal as compared with recent experience. Details relative to cycles of: operation during the quarter are given. in Table 2, while Figures 1 and 2 are plots of shim-rod position versus time for these cycles. 
Table 1, " ORR Basic Operating Data April, May, and June of 1976

\begin{tabular}{|c|c|c|c|c|}
\hline & $\begin{array}{l}\text { This } \\
\text { Quarter } \\
\end{array}$ & $\begin{array}{l}\text { Last } \\
\text { Quarter }\end{array}$ & $\begin{array}{l}\text { Year } \\
\text { To Date } \\
\end{array}$ & $\begin{array}{c}\text { January through } \\
\text { June, } 1975 \\
\end{array}$ \\
\hline Tota1 energy, MWd & $2,434.8$ & $2,254.5$ & $4,689.2$ & $4,555.1$ \\
\hline $\begin{array}{l}\text { Average power, } \\
\text { MW/operating } h r\end{array}$ & 29.7 & 29.9 & 29.8 & 29.8 \\
\hline Time operating, \% & 90.0 & 82.8 & 86.4 & 85.2 \\
\hline Availability, \% & 95.5 & 90.6 & 93.1 & 09.5 \\
\hline $\begin{array}{l}\text { Reactor water radiua } \\
\text { activity } \frac{\mathrm{c} / \mathrm{min}}{\mathrm{ml}} \text { (av) }\end{array}$ & $29 ; 400$ & 28,200 & 28,800 & 30,000 \\
\hline $\begin{array}{l}\text { Pool water radio- } \\
\text { activity } \frac{\mathrm{c} / \mathrm{min}}{\mathrm{ml}} \text { (av) }\end{array}$ & 580 & 610 & 595 & 670 \\
\hline $\begin{array}{l}\text { Reactor water resis- } \\
\text { tivity, ohm-cm (av) }\end{array}$ & $844 ; 000$ & 822,000 & 833,000 & 850,000 \\
\hline $\begin{array}{l}\text { Pool water resis- } \\
\text { tivity, ohm-cm (av) }\end{array}$ & $700 ; 000$ & 799,000 & 749,500 & 785,000 \\
\hline Fuel elements depleted & 9 & 2 & 11 & 45 \\
\hline $\begin{array}{l}\text { Average burnup of fuel } \\
\text { elements depleted, } \%\end{array}$ & 55.3 & 58.8 & 56.0 & 52.9 \\
\hline Shim rods depleted & 2 & 4 & 6 & 8 \\
\hline $\begin{array}{l}\text { Averagc burnup of shim } \\
\text { rods depleted, } \%\end{array}$ & 62.5 & 64.4 & 63.5 & 64.6 \\
\hline Radioisotope samples & 2 & 0 & 2 & 19 \\
\hline Research samples & 5 & 1 & 6 & 23 \\
\hline
\end{tabular}

Table 2. Cycles of Operation

\begin{tabular}{cccc}
\hline Cycle No. & Date Begun & Date Ended & $\begin{array}{c}\text { Accumulated Énergy } \\
\text { (MWd) }\end{array}$ \\
\hline 131 & Apri1 1, 1976 & May 22, 1976 & $1,423.7$ \\
132 & May 27, 1976 & In progress & $1,011.1$ \\
\hline
\end{tabular}


ORNL OHG. 76-18194

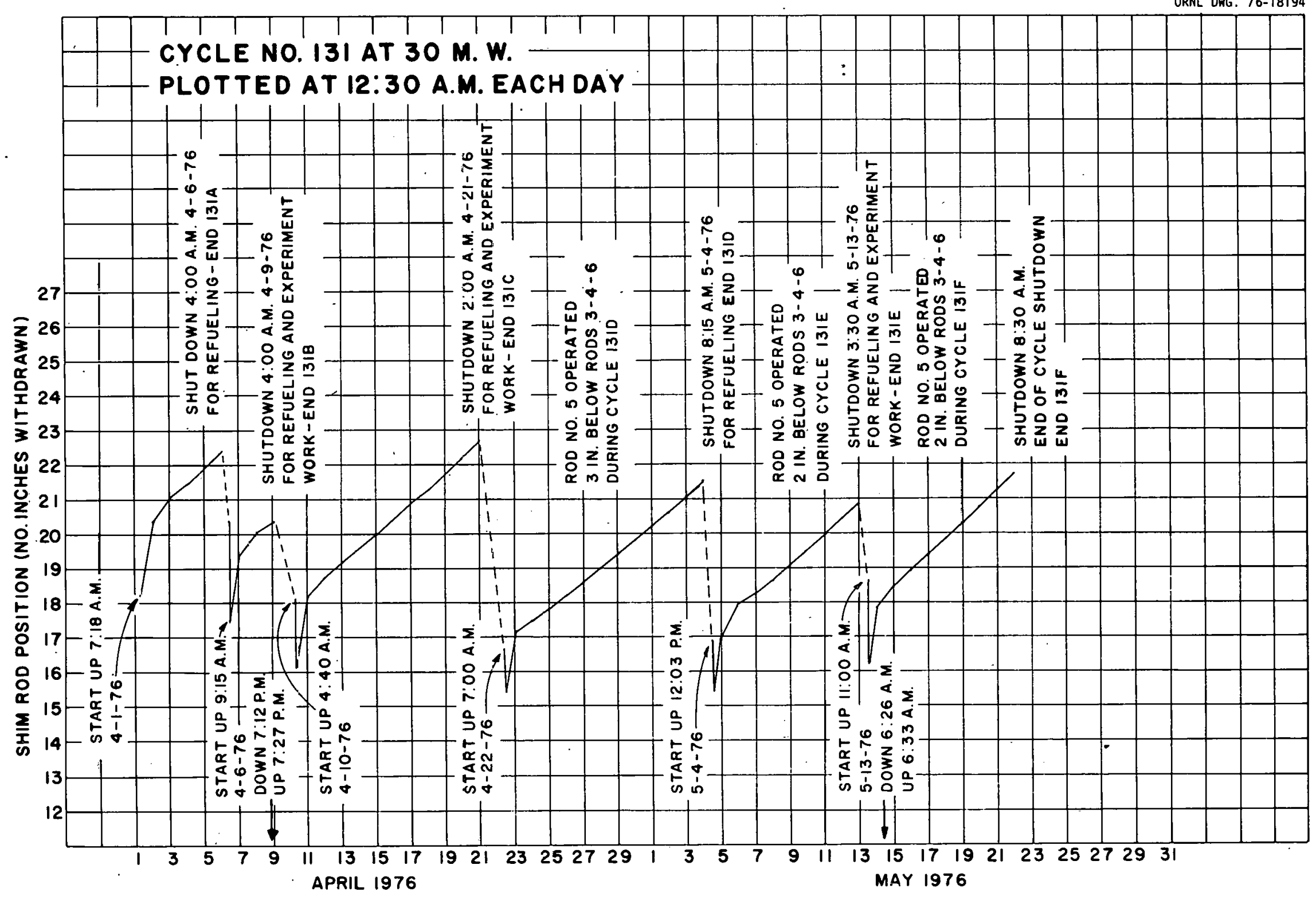

Figure 1. Shim Rod Position vs Time (Cycle 131) 


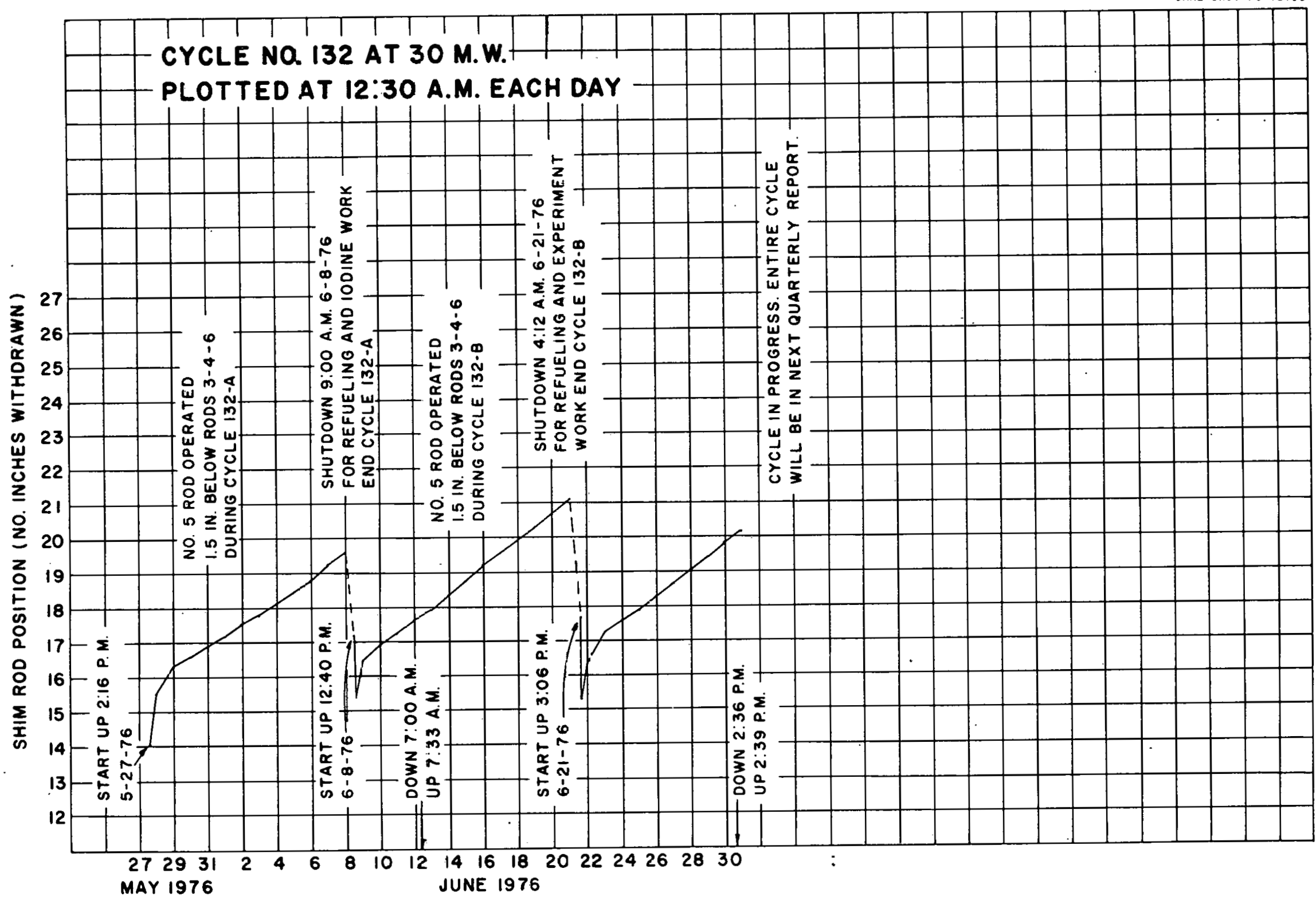

Figure 2. Shim Rod Position vs Time (Cycle 132) 
FUEL USAGE AND INVENTORY

Twenty-five new fuel: elements were placed in service during the quarter and twenty-five were declared spent with an average burnup of $52.3 \%$ Other details of fuel usage and inventory may be found in Tables 1 and 3 .

Table 3. ORR Fuel Status

\begin{tabular}{|c|c|c|c|c|}
\hline$\cdots \cdots$ & $\begin{array}{l}\text { This } \\
\text { Quarter } \\
\end{array}$ & $\begin{array}{l}\text { Last } \\
\text { Quarter }\end{array}$ & $\begin{array}{c}\text { Jan -June } \\
1976 \\
\end{array}$ & $\begin{array}{c}\text { Jan-June } \\
1975 \\
\end{array}$ \\
\hline $\begin{array}{l}\text { Depleted fuel elements trans- } \\
\text { ferred for chemical separa- } \\
\text { tion }\end{array}$ & .0 & 45 & 45 & 93 \\
\hline $\begin{array}{l}\text { Average percent burnup of fuel } \\
\text { elements transferred }\end{array}$ & - & 52.0 & 52.0 & 48.7 \\
\hline $\begin{array}{l}\text { New fuel elements placed in } \\
\text { service }\end{array}$ & 25 & 28 & 53 & 33 \\
\hline $\begin{array}{l}\text { New fuel elements available } \\
\text { for use }\end{array}$ & $68 *$ & 93 & & \\
\hline $\begin{array}{l}\text { Depleted shim rods transferred } \\
\text { for chemical separation }\end{array}$ & 0 & 6 & 6 & 12 \\
\hline $\begin{array}{l}\text { Average percent. burnup of shim } \\
\text { rods transferred }\end{array}$ & -- & 65.0 & 65.0 & 65.0 \\
\hline $\begin{array}{l}\text { New shim rods placed in ser- } \\
\text { vice }\end{array}$ & 2 & 4 & 6. & 8 \\
\hline New shim rods available for use. & 0 & 0 & & \\
\hline
\end{tabular}

*Includes 4 partial-fuel elements. 


\section{SHUTDOWNS AND POWER REDUCTIONS}

Reactor downtime (power level $<\mathrm{N}_{\mathrm{L}}$ ) totaled approximately 218 hours A summary of the shutdowns is given in Table: 4, and details of each are contained in Table 5. Table 6 offers Information relative to the unscheduled shutdowns.

Table 4. Sumnary of Shutdowns

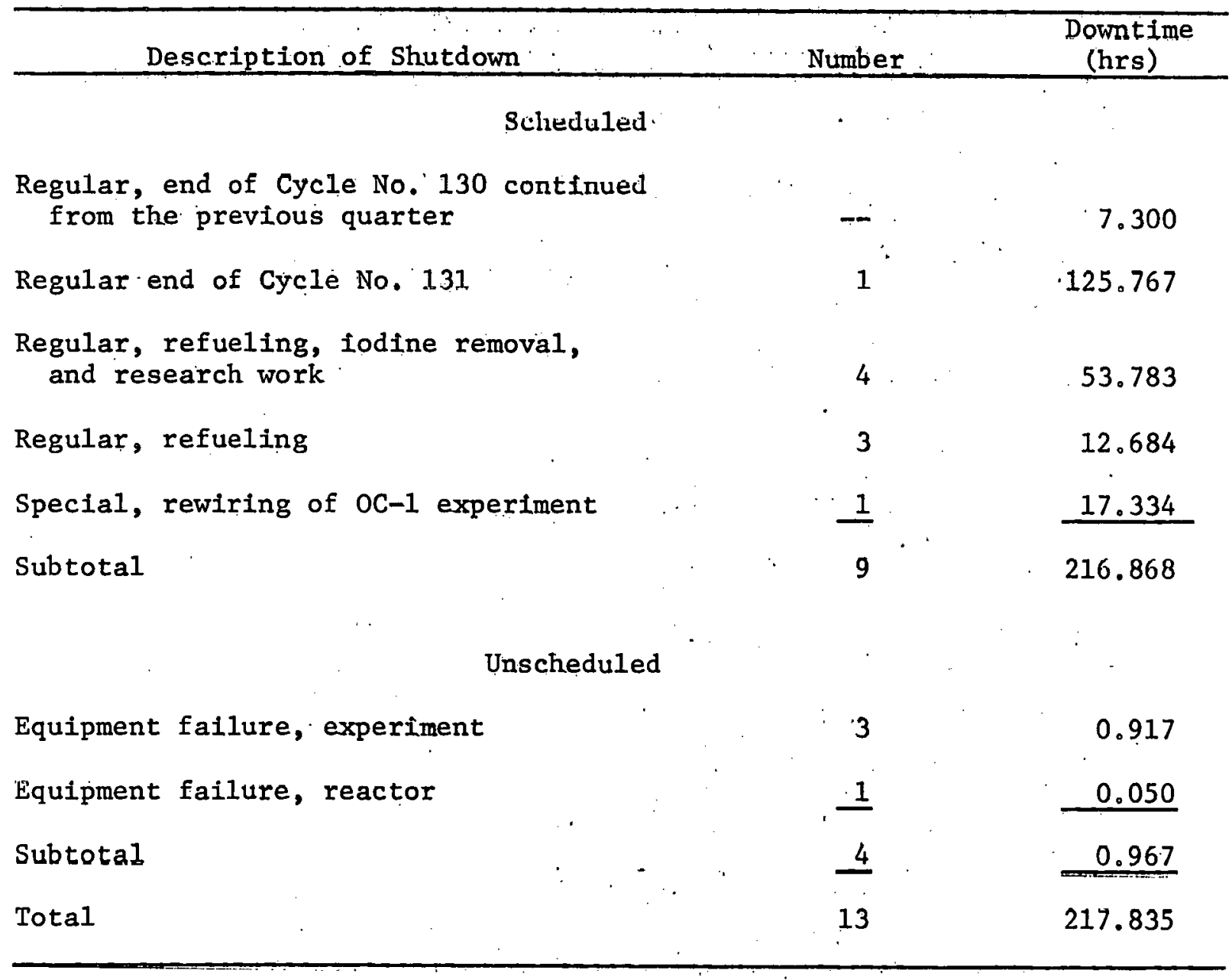


Table 5. ORR Scheduled Shutdowns, Detalls.

\begin{tabular}{|c|c|c|c|}
\hline Date & $\begin{array}{c}\text { Duration } \\
\text { (hr) }\end{array}$ & $\begin{array}{c}\text { End } \\
\text { Cycle }\end{array}$ & Remarks \\
\hline $4-1-76$ & 7.300 & $130 \mathrm{C}$ & $\begin{array}{l}\text { The end-of-cycle shutdown work as listed in the previous ORR quarterly } \\
\text { report was completed. }\end{array}$ \\
\hline $4-6-76$ & 5.250 & $131 \mathrm{~A}$ & The reactor was refueled. \\
\hline $4-9-76$ & 6.383 & $131 \mathrm{~B}$ & $\begin{array}{l}\text { The reactor was refueled and isotope (iodine-xenon) work was completed. } \\
\text { Experiment work consisted of inspection of wiring to heaters on the } \\
\text { oc-1 experiment. }\end{array}$ \\
\hline $4-9-76$ & 17.334 & & $\begin{array}{l}\text { The reactor was shut down to permit rewiring of the in-pool electrical } \\
\text { connections for the heaters on the OC-1 experiment. }\end{array}$ \\
\hline $4-21-76$ & 29.000 & $131 \mathrm{C}$ & $\begin{array}{l}\text { The reactor was refueled and isotope (iodine-xenon) work was completed. } \\
\text { Experiment work consisted of the removal of one experiment and instal- } \\
\text { lation of two for the Metals and Ceramics Division. One experiment } \\
\text { was installed for the Reactor Division. }\end{array}$ \\
\hline $5-4-76$ & 3.800 & 131D & The reactor was refueled. \\
\hline $5-13-76$ & 7.500 & $131 \mathrm{E}$ & $\begin{array}{l}\text { The reactor was refueled and isotope (iodine-xenon) work was completed. } \\
\text { Experiment work consisted of the installation of a nose cone experi- } \\
\text { ment for General Electric. }\end{array}$ \\
\hline $5-22-76$ & 125.767 & $131 \mathrm{~F}$ & $\begin{array}{l}\text { The shutdown marked the end of cycle } 131 \text {. The first } 8.500 \text { hours were } \\
\text { for. Family Day-Open House. Shutdown activities included: (1) pro- } \\
\text { gramed: maintenance on the centravac; (2) replacement of tubes in the } \\
\text { radiator on the diesel unit; (3) replacement of worn insulation on } \\
\text { outside water and steam lines; (4) installation of the pipe supports } \\
\text { and grating at the primary water pump house; (5) inspection of the } \\
\text { front face of the reactor tank; (6) removal of the oc-1 experiment } \\
\text { from.CP-E5; and ( } 7 \text { ) replacement of a broken operator on the reactor } \\
\text { primary bypass valve. }\end{array}$ \\
\hline
\end{tabular}


Table 5 (continued)

\begin{tabular}{|c|c|c|c|}
\hline Date & $\begin{array}{c}\text { Duration } \\
\text { (hr) }\end{array}$ & $\begin{array}{c}\text { End } \\
\text { Cycle }\end{array}$ & Remarks \\
\hline $5-8-76$ & 3.634 & $132 \mathrm{~A}$ & The reactor was refueled and isotope (iodine-senon) work was completed. \\
\hline $6-21-76$ & 10.900 & $132 \mathrm{~B}$ & $\begin{array}{l}\text { The recctor was refueled and isotope (iojine-xenon) work was completed. } \\
\text { Experinent wo-k consisted of removal oE experiments B-8 and P-5 for } \\
\text { the Metals and Ceramics Division, and the Te-Gen experiment for the } \\
\text { Reactor Division. }\end{array}$ \\
\hline
\end{tabular}

Table 6. ORR. Unscheduled Shutdowns, Details

\begin{tabular}{|c|c|c|}
\hline Date & $\begin{array}{l}\text { Duration } \\
\text { (hr) }\end{array}$ & Remarks \\
\hline $4-8-76$ & 0.250 & $\begin{array}{l}\text { The reactor was shut lown when a thermocouple switch on the oC-1 experiment } \\
\text { failed causing an instrument power failure. }\end{array}$ \\
\hline $5-14-76$ & 0.117 & a thermocouple failed on the $\mathrm{OC}-1$ experiment. \\
\hline $6-12-76$ & 0.550 & $\begin{array}{l}\text { The safety power breaker on experiment GB-10 tripped causing the reactor to. } \\
\text { shut down. }\end{array}$ \\
\hline $6-30-76$ & 0.050 & $\begin{array}{l}\text { During a filter change at the stack area on the MDG system, the pressure on the } \\
\text { NOG increased to a negative } 19 \mathrm{in.} \mathrm{H}_{2} \mathrm{O} \text { resulting in a setback and a momentary } \\
\text { power sag below } \mathrm{N}_{\mathrm{L}} \text {. }\end{array}$ \\
\hline
\end{tabular}


INSTRUMENTATION AND REACTOR CONTROLS

The performance of the instrumentation for the complex was quite satisfactory and. only' routine maintenance was. required as indicated in Table 7. Table 8 reflects the status of the various fission and ionization chambers.

\section{PROCESS SYSTEM AND MECHANICAL COMPONENTS}

Details of malntenance or changes to the process system are given. in Table 9. Table 10 sumarizes the results of effictency tests of the various gaseous waste filters. There were ho repairs or changes related to the reactor mechanical components (drives; bearings, etco)。

EXPERIMENT PACILITIIES AND CORE CHANGES

Experiment facility usage is given in Table 11. The core configuration used during the quarter is shown. In F1gures 3,4, and 5.

\section{SPECIAÏ TESTS}

Visual Inspection of Poolside Facility

On May 24, 1976, a visual examination of the outside of the poolside irradiation facility was made:

The north half of the poolside "window": and the lower quarter of the south half were examined through the use of the underwater omiscope (four power magniflcation). Superficlal scratches; apperently, the result of experiment installations, were observed as has been the case in previous examinations. No increase in corrosion, pitting, or any other damage was found. 
Table 7: Maintenance and Cinanges, Instrumentation and Controls

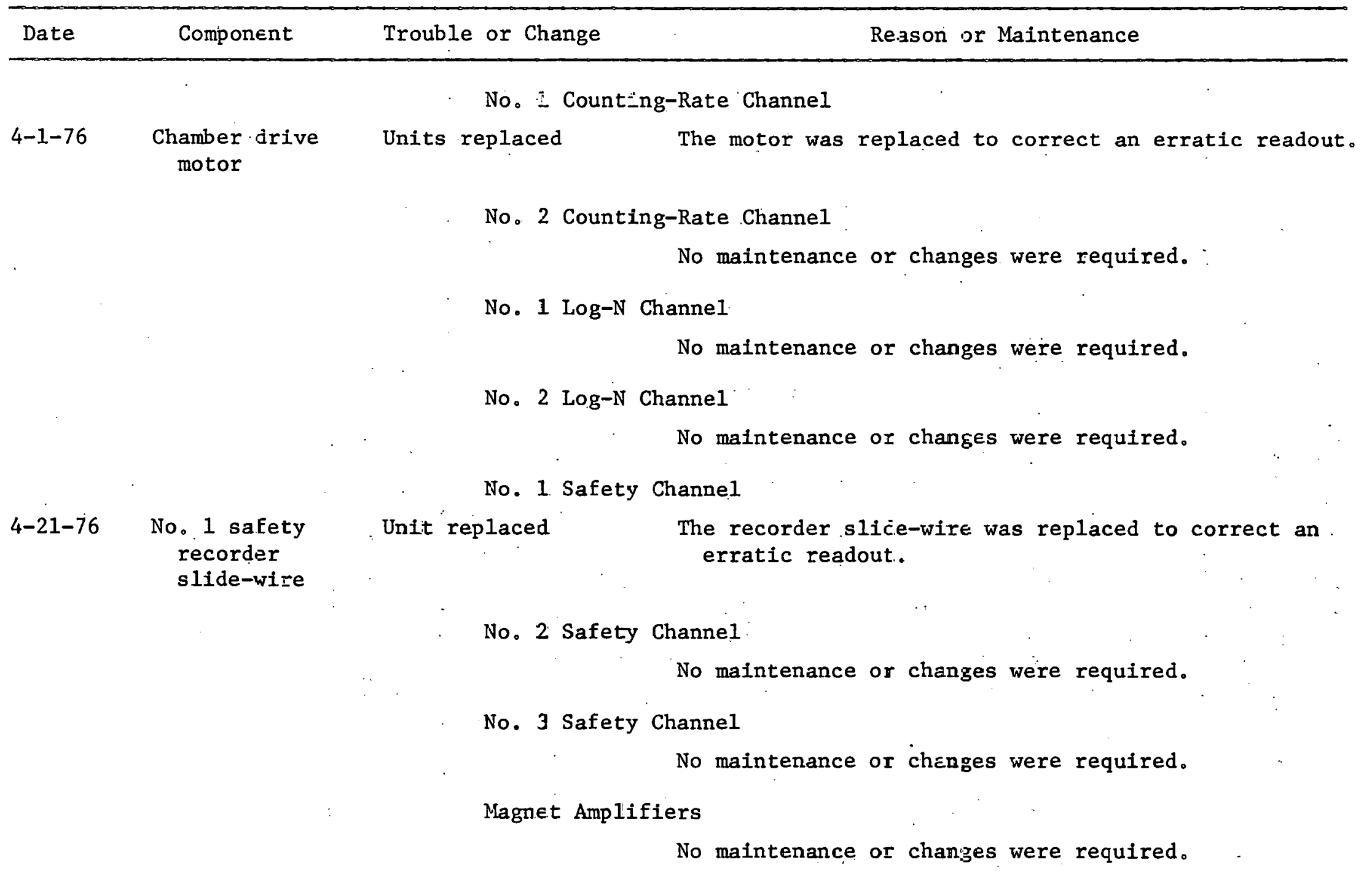


Tạble 7 (continued)

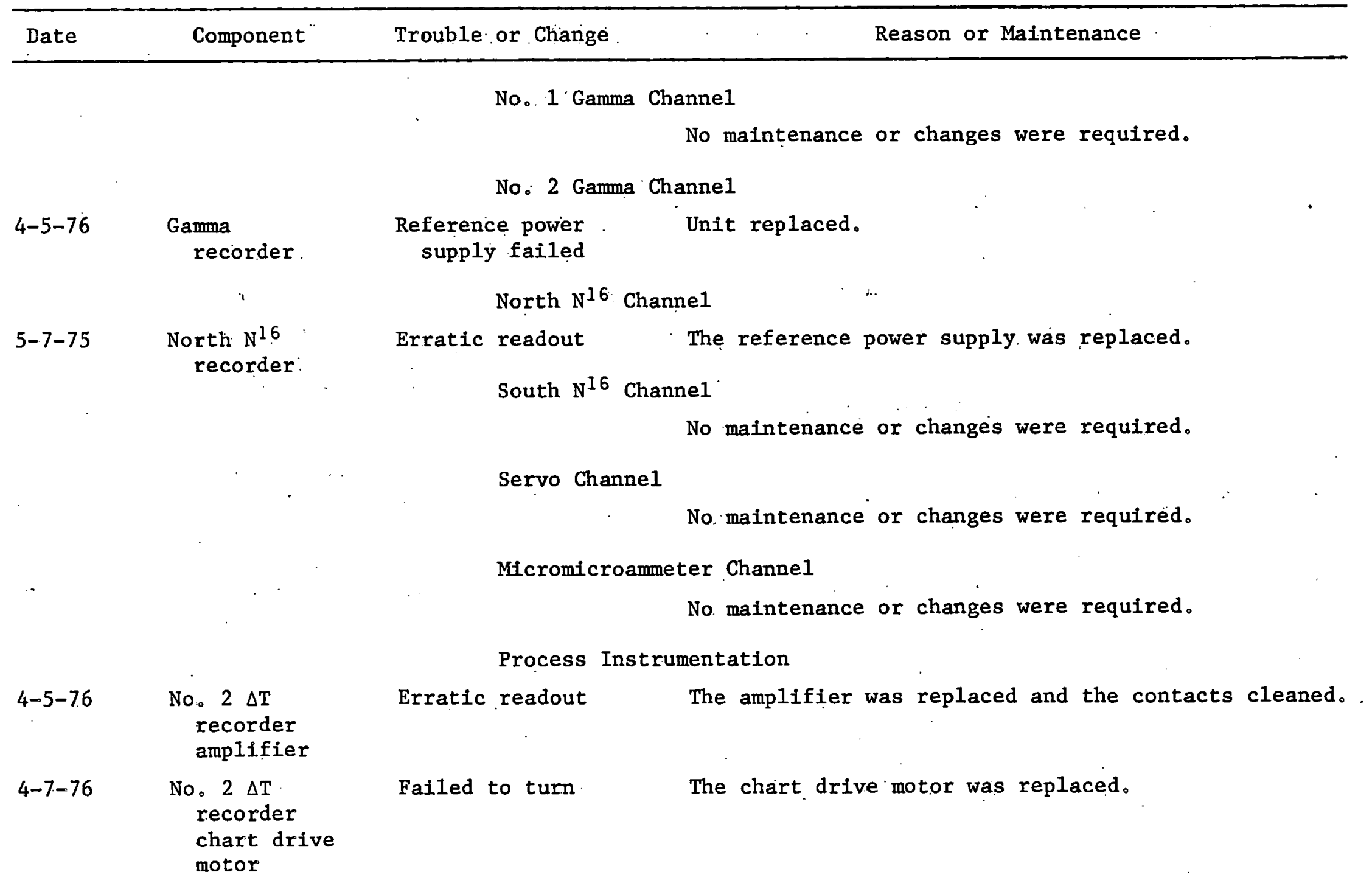


Table 7 (continued)

\begin{tabular}{|c|c|c|c|}
\hline Date & Comporient & Trouble or Change & Reason or Maintenance \\
\hline $5-12-76$ & $\begin{array}{l}\text { No. } 2 \Delta \mathrm{T} \\
\text { record } \geqq r\end{array}$ & Incorrect readout & The recorder slice-wire was replaced. \\
\hline $4-29-76$ & $\begin{array}{l}\text { No. } 2 \text { outlet } \\
\text { temperiture } \\
\text { recorder }\end{array}$ & Erratic readout & $\begin{array}{l}\text { The amplifier was replaced and the slide-wire was } \\
\text { cleaned. }\end{array}$ \\
\hline $6-1-76$ & $\begin{array}{l}\text { No. } 2 \text { outlet } \\
\text { temperature } \\
\text { recorder }\end{array}$ & Erratic readout & The amplifier was replaced. \\
\hline $6-16-76$ & $\begin{array}{l}\text { No. } 2 \text { outlet } \\
\text { temperature } \\
\text { recorder. }\end{array}$ & Erratic readout & The amplifier anc the balance motor were replaced. \\
\hline $6-16-76$ & $\begin{array}{l}\text { Normal cef-gas } \\
\text { (NOG) Eilter } \\
\text { pits tempera- } \\
\text { ture recorder }\end{array}$ & Erratic readout & The battery was replaced. \\
\hline $6-1-76$ & $\begin{array}{l}\text { Poo1 water } \\
\text { activity } \\
\text { recorder }\end{array}$ & Irratic readout & The amplifier was replaced. \\
\hline
\end{tabular}


Table 8. Present Status of Ionization Chambers and Fission Chambers

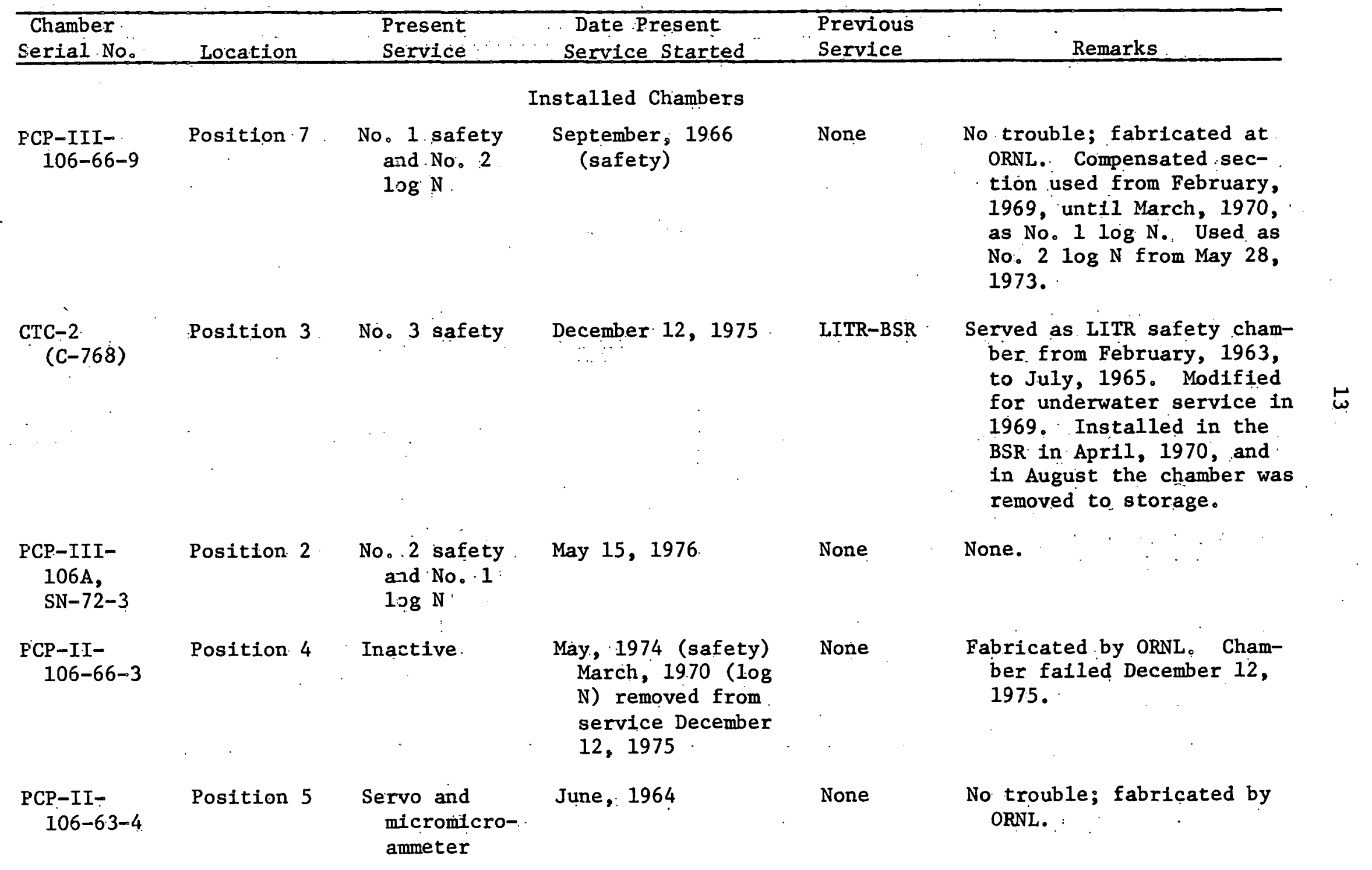


Table 8 (continued)

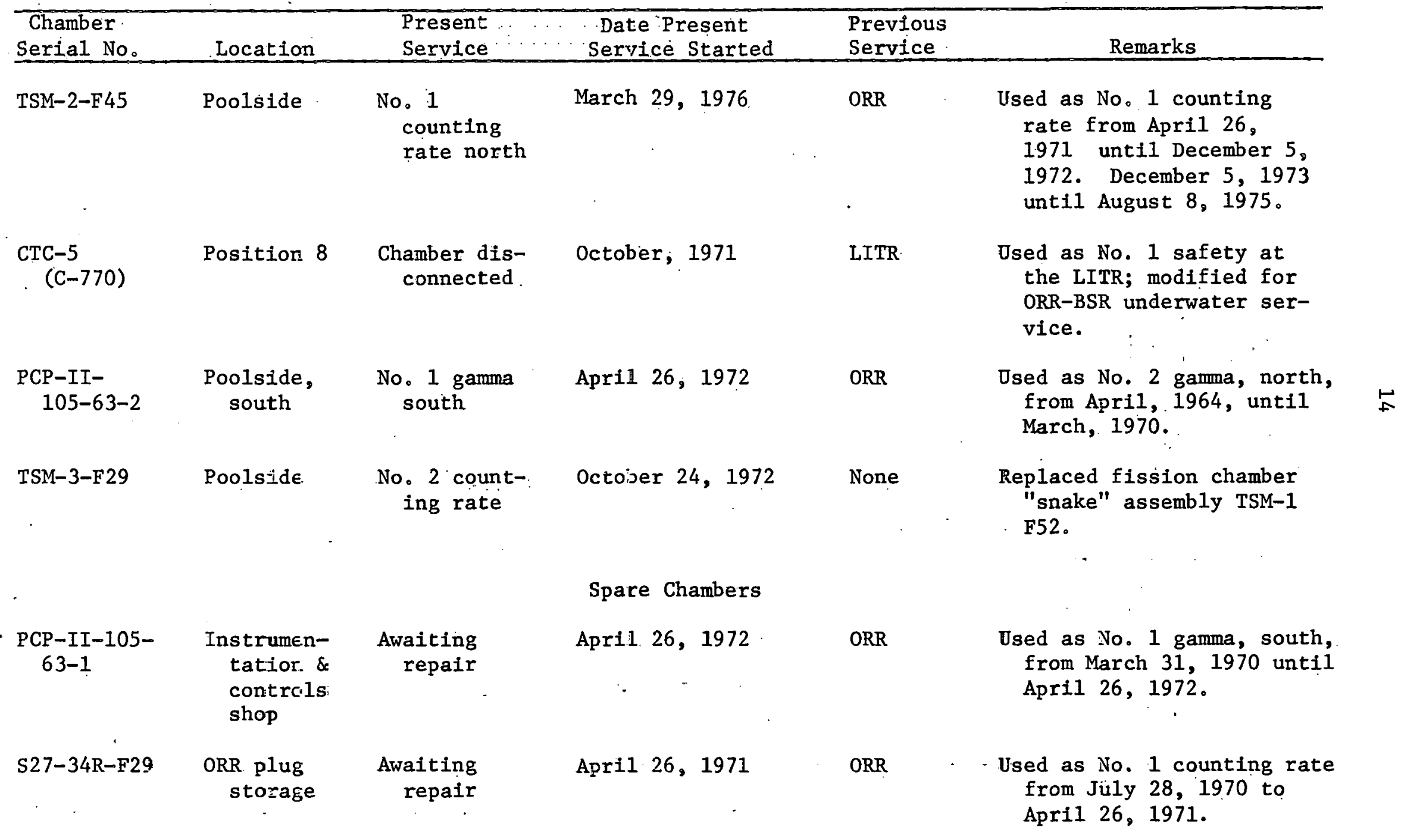


Table 8 (continued)

\begin{tabular}{|c|c|c|c|c|c|}
\hline $\begin{array}{l}\text { Chamber } \\
\text { Serial No. }\end{array}$ & Location & $\begin{array}{l}\text { Present } \\
\text { Service }\end{array}$ & $\begin{array}{l}\text { Date Present } \\
\text { Service Started }\end{array}$ & $\begin{array}{l}\text { Previous } \\
\text { Service. }\end{array}$ & Remarks \\
\hline $\mathrm{S} 3-8 \mathrm{R}-\mathrm{F} 22$ & $\begin{array}{l}\text { ORR plug } \\
\text { storage: }\end{array}$ & $\begin{array}{l}\text { Awaiting } \\
\text { repair. }\end{array}$ & April 26, 1971 & ORR & $\begin{array}{l}\text { Used as No. } 2 \text { counting rate } \\
\text { from January } 14,1970 \text { to } \\
\text { April 26, } 1971 .\end{array}$ \\
\hline CTC-1 & $\begin{array}{l}\text { Instrumen- } \\
\text { tation \& } \\
\text { controls } \\
\text { shop. }\end{array}$ & $\begin{array}{l}\text { Awaiting } \\
\text { repair }\end{array}$ & October, 1971 & ORR & $\begin{array}{l}\text { Used as noise monitor from } \\
\text { March, } 1962 \text { until October } \\
\text { 1, 1971. }\end{array}$ \\
\hline $\begin{array}{l}\mathrm{CTC}-4 \\
(\mathrm{C}-769)\end{array}$ & $\begin{array}{l}\text { ORR plug } \\
\text { storage }\end{array}$ & ، & . & IITR & $\begin{array}{l}\text { Used as No. } 2 \text { safety in the } \\
\text { LITR; modified for ORR- } \\
\text { BSR underwater service. }\end{array}$ \\
\hline $\begin{array}{l}\text { PCF-III- } \\
\text { 106-66-5 }\end{array}$ & $\begin{array}{l}\text { Instrumen- } \\
\text { tation \& } \\
\text { controls } \\
\text { shop }\end{array}$ & $\begin{array}{r}\text { Awaiting } \\
\text { repair }\end{array}$ & 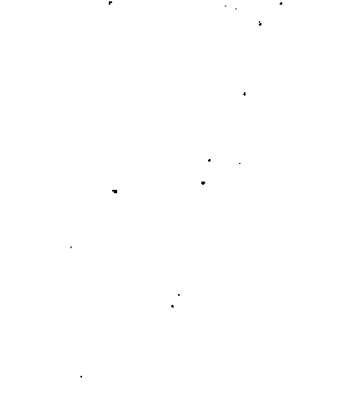 & ORR. & $\begin{array}{l}\text { Used as No. } 2 \text { safety and } \\
\text { log N from September } 27 \text {, } \\
1968 \text { to. July } 22,1970 \\
\text { and from May } 7,1971 \text { to } \\
\text { May } 20,01971 ; \text { from } \\
\text { November, } 1971 \text { to January } \\
24,1973 \text { as No. } 2 \text { safety } \\
\text { and unti1 May } 28,1973 \text { as } \\
\text { No. } 2 \text { log N. }\end{array}$ \\
\hline TSM-2-F45 & $\begin{array}{l}\text { Poolside } \\
\text { I\&C shop }\end{array}$ & $\begin{array}{l}\text { Awaiting } \\
\text { repair }\end{array}$ & August 8, 1975 & ORR & $\begin{array}{l}\text { Used as No. } 1 \text { counting rate } \\
\text { from April } 26,1971 \text { until } \\
\text { December } 5,1972 . \\
\text { Removed March } 30,1976 \text { to } \\
\text { shop for repair. }\end{array}$ \\
\hline
\end{tabular}


Table 9. Process Systems, Maintenance and Changes

\begin{tabular}{|c|c|c|}
\hline Date & Comporent & Remarks \\
\hline \multicolumn{3}{|c|}{ Reactor Primary Water System } \\
\hline $4-9-76$ & Degasifier system & A ruptured diaphragm was replaced in the No. 2 valve. \\
\hline $4-26-76$ & Degasifier demineralizer & $\begin{array}{l}\text { A faulty diaphragm and gasket } \nabla \in \text { re replaced in valve No. } \\
\text { D-8. }\end{array}$ \\
\hline $5-25-76$ & Bypass filters & The filter cartridges were changed. \\
\hline $5-25-76$ & Reactor primary bypass valve & A broken operator was replaced. \\
\hline $5-26-76$ & $\begin{array}{l}\text { Reactor primary water line } \\
\text { modifications at the pump } \\
\text { house (Bldg. 3085) }\end{array}$ & $\begin{array}{l}\text { The floor grating and water line supports were installed in } \\
\text { the new excavated areas around and under the primary } \\
\text { water lines. }\end{array}$ \\
\hline \multicolumn{3}{|c|}{ Reactor Secondary Cooling System } \\
\hline $4-1-76$ & Fan controller (north fan) & A broken wire to the fan was repaired. \\
\hline $\begin{array}{l}6-25-76 \\
\text { through } \\
6-28-76\end{array}$ & Acid addition system & A leak in the acid line was repaired. \\
\hline \multicolumn{3}{|c|}{ Pool Primary Cooling System } \\
\hline $5-26-76$ & Demineralizer system & The strainers were checked and cleaned as needed. \\
\hline & \multirow[t]{2}{*}{ Emergency } & y Cooling System \\
\hline $4-13-76$ & & $\begin{array}{l}\text { The annual checks were performed. The oil was changed, new } \\
\text { spark plugs were installed, and the motor was tuned. }\end{array}$ \\
\hline $5-26-76$ & Nos. 1,2 , and $3 \mathrm{dc}$ units & $\begin{array}{l}\text { Functional tests of equipment and alarms confirmed that the } \\
\text { systems were in satisfactory concition. }\end{array}$ \\
\hline
\end{tabular}


Table 9 (continued)

Date Component $\ldots, \ldots, \cdots, \cdots, \quad$ Remarks

\section{Electrical Systems}

5-24-76 Misce1laneous breaker panels for electric motors, dc batteries, battery racks,

Routine end-of-cycle inspection and cleaning were performed. overhead crane, and control room instrument

cabinets Dust filters for the control room instrument cabinets were changed as needed.

$\begin{array}{ll}5-24-76 & \text { Diesel generator } \\ 5-26-76 & \text { Diese1. generator }\end{array}$

$4-13-76$

$4-23-76$

$4-28-76$

$4-28-76$

$5-3-76$

$5-6-76$

$5-7-76$
East oank.

\section{Emergency Electrical System}

Two sections of faulty radiator tubes were replaced.

The routine end-of-cycle load test was performed with satisfactory results.

Normal Off-Gas System

New filters were installed.

Misce11 aneous

Main steam line entering ORR (B1dg, 3042)

Stean supply

Heating and ventilation unit No. 3

Steam supply

Caustic supply line in the ORR basement
A meter was installed in the steam line on the north side of the building over the laboratory in the ORR basement.

A leak on the main supply. line over the laboratory in the ORR basement was repaired.

A steam leak to the unit was repaired.

A faulty valive on the main supply line located over the laboratory in the ORR basement was replaced. The steam line was then insulated.

A ruptured diaphragm in valve No. 23 was replaced. 
Table 9 (continued)

\begin{tabular}{|c|c|c|}
\hline Date & Componen: & Remarks \\
\hline $5-18-76$ & Fuel reloading tool & $\begin{array}{l}\text { A new foot piece was installed on one fuel reloading tool. } \\
\text { The one removed was inoperative. }\end{array}$ \\
\hline $\begin{array}{l}5-18-76 \\
5-21-76\end{array}$ & Air conditioning & $\begin{array}{l}\text { An air-conditioning unit was installed in Room No. } 300 \\
\text { because computers located in this room require a backup } \\
\text { system. }\end{array}$ \\
\hline $5-25-76$ & $\begin{array}{l}\text { Air-conditioner sooling } \\
\text { towers. }\end{array}$ & Several faulty louvers were replaced. \\
\hline $5-25-76$ & New purp, south of E1dg. 3085 & A receptacle and 1 ight were installed. \\
\hline $\begin{array}{l}6-22-76 \\
6-28-76\end{array}$ & Sump pump No. 3 & $\begin{array}{l}\text { A faulty switch was replaced. A sticking float switch was } \\
\text { repaired. }\end{array}$ \\
\hline
\end{tabular}


Table 10。 Status of Filters - Gaseous Waste System

\begin{tabular}{|c|c|c|c|c|c|}
\hline $\begin{array}{c}\text { Type } \\
\text { Filter }\end{array}$ & $\begin{array}{c}\text { Bank } \\
\text { Designation }\end{array}$ & Date Installed & $\begin{array}{l}\text { Date Last } \\
\text { Tested }\end{array}$ & Type Test & $\begin{array}{c}\text { Retention } \\
\text { Efficiency }(\%) \\
\end{array}$ \\
\hline \multicolumn{6}{|c|}{ Ce11 Ventilation System } \\
\hline CWS & Overall* & $\begin{array}{l}\text { North, } 6-20-73 \\
\text { South, } 1-12-65\end{array}$ & $\begin{array}{l}3-24-76 \\
3-24-76\end{array}$ & DOP & 99.993 \\
\hline Charcoal. & Both banks & $\begin{array}{l}\text { North, } 9-16-74 \\
\text { South, 10-17-67 }\end{array}$ & $3-2-76$ & Elemental Iodine & 99.97 \\
\hline Charcoal & Both banks & $\begin{array}{l}\text { North, } 9-16-74 \\
\text { South, } 10-17-67\end{array}$ & $3-4-76$ & Methy1 Iodine & 34.22 \\
\hline \multicolumn{6}{|c|}{ Pressurizable off-Gas } \\
\hline CWS & North & $5-5-76$ & $3-24-76$ & DOP & 99.965 \\
\hline CWS & South & $10-18-67$ & $3-24-76$ & DOP. & 99.992 \\
\hline Charcoal & North & $2-26-73$ & $10-7-75$ & Elemental Iodine & 87.97 \\
\hline Charcoal & South & $8-11-75$ & $10-8-75$ & Elemental Iodine & 97.48 \\
\hline Charcoal & North & $2-26-73$ & $1-28-76$ & Methyl Iodide & 99.94 \\
\hline Charcoal. & South & $\varepsilon-11-75$ & $8-13-75$ & Methy1 Iodide & 99.993 \\
\hline
\end{tabular}

*The CWS filters in the cell ventilation system were checked in series。 
TEble $10 \ldots$ (continued)

\begin{tabular}{|c|c|c|c|c|c|}
\hline $\begin{array}{c}\text { Type } \\
\text { Filter } \\
\end{array}$ & $\begin{array}{c}\text { Bank : } \\
\text { Designation }\end{array}$ & $\begin{array}{lllll}\ldots & \ldots \ldots & \ldots & \ldots \ldots \\
\text { Date } & \text { Installed } \\
\end{array}$ & $\begin{array}{l}\text { Date Last } \\
\text { Tested }\end{array}$ & Type Test & $\begin{array}{c}\text { Retention } \\
\text { Efficiency. }(\%) \\
\end{array}$ \\
\hline \multicolumn{6}{|c|}{ Basemer.t Hood Exhaust } \\
\hline CWS & South & $2-16-72$ & $3-15-76$ & DOP & 99.996 \\
\hline CWS & Nortic & $2-16-72$ & $3-15-76$ & DOP & 99.995 \\
\hline \multicolumn{6}{|c|}{ Normal off-Gas } \\
\hline CWS & West & $2-12-76$ & $3 \div 24-76$ & $\mathrm{DOP}$ & 99.996 \\
\hline CWS & East & $6-12-75$ & $3-24-76$ & DOP & 99.998 \\
\hline Charcoal & West & $2-12-76$ & $2-17-76$ & Elemental Iodine & 99.99 \\
\hline Charcoal & East & $7-29-75$ & $4-13-76$. & Elemental Iodine & 99.99 \\
\hline Charcoal & West & $2-12-76$ & $4-20-76$ & Methyl. Iodide & 99.93 \\
\hline Charcoal & East & $7-29-75$ & $4-20-76$ & Methy1 Iödide & 94.14 \\
\hline
\end{tabular}


Table 11。 Experiment Facility Usage

\begin{tabular}{|c|c|c|c|c|c|}
\hline Facility & $\begin{array}{l}\text { Access } \\
\text { Flange }\end{array}$ & $\begin{array}{c}\text { Date } \\
\text { Installed }\end{array}$ & $\begin{array}{c}\text { Date } \\
\text { Removed }\end{array}$ & Description of Experiment & $\begin{array}{l}\text { Division or } \\
\text { Other Sponsor }\end{array}$ \\
\hline$A-3$ & None & $8-15-75$ & $6-21-76$ & Radioisotopes (iodine and xenon) & Isotopes \\
\hline$B-8$ & $v-1$ & $1-27-76$ & $4-21-76$ & $\begin{array}{l}\text { Four internally pressurized } \mathrm{Zr} \\
\text { capsules }\end{array}$ & Metals and Ceramics \\
\hline$B-8$ & $\mathrm{~V}-1$ & $4-2 I-76$ & $6-21-76$ & $\begin{array}{l}\text { Four internally pressurized } \mathrm{Zr} \\
\text { capsules }\end{array}$ & Metals and Ceramics \\
\hline $\mathrm{B}-8$ & None. & $6-21-76$ & & Radioisotopes (iodine and xenon) & Operations \\
\hline $\mathrm{C}-3$ & None & $3-21-76$ & $4-21-76$ & Silicon sample & Solid State. \\
\hline $\mathrm{D}-8$ & $v-3$ & $3-10-67$ & & $\begin{array}{l}\text { Hydraulic tube No. } 2 \text { used for } \\
\text { isotope production and short- } \\
\text { term irradiations }\end{array}$ & Operațions \\
\hline$E-3$ & $V-9$ & $5-6-75$ & & P-13T capsule experiment & Reactor \\
\hline$E-5$ & $\nabla-6$ & $3-29-76$ & $5-21-76$ & oC-1 capsule experiment & Reactor \\
\hline$E-7$ & $\nabla-5$ & $6-20-75$ & & OF-2 capsule experiment & Reactor \\
\hline$P-4 \mathrm{~A}$ & None & $4-21-76$ & $6-21-76$ & TeGen IV capsule experiment & Reactor \\
\hline$P-5$ & Mone & $4-21-76$ & $6-21-76$ & Tensile specimens & Metals and Ceramics \\
\hline $\mathrm{P}-7-\mathrm{P} 8$ & None & $5-13=76$ & $5-18-76$ & Nose cone experiment & General Electric \\
\hline$G C R-P 7-A$ & None & $8-8-72$ & & GB-10 capsule experiment & Reactor. \\
\hline
\end{tabular}


Table 11 (continued)

\begin{tabular}{|c|c|c|c|c|c|}
\hline Facility & $\begin{array}{l}\text { Access } \\
\text { Flange }\end{array}$ & $\begin{array}{c}\text { Date. } \\
\text { Installed }\end{array}$ & $\begin{array}{c}\text { Date } \\
\text { Removed }\end{array}$ & Description of Experinezt & $\begin{array}{l}\text { Division or } \\
\text { Other Sponsor }\end{array}$ \\
\hline $\mathrm{HB}-2$ & None & $7-58$ & & Neutron diffraction experiment & Solid State-Physics \\
\hline$B-3$ & None & $11-59$ & & Neutron diffraction experiment & Solid State-Physics \\
\hline $\mathrm{HB}-4$ & None & $7-58$ & & Neutron diffraction experiment & Chemistry \\
\hline HB-6 & None & & & & Solid State \\
\hline $\mathrm{HN}-3$ & None & $11-59$ & & Activation analysis & $\begin{array}{l}\text { Analytical } \\
\text { Chemistry }\end{array}$ \\
\hline $\mathrm{HN}-4$ & None & $12-15-63$ & & $\begin{array}{l}\text { Void determination in irradiated } \\
\text { materials }\end{array}$ & Solid State-Physics \\
\hline $\mathrm{HN}-4$ & None & $12-15-63$ & & $\begin{array}{l}\text { "Fly's Eye" two-dimensional } \\
\text { neutron diffraction and } \\
\text { radiography. }\end{array}$ & $\begin{array}{l}\text { Instrumentation } \\
\text { and Controls }\end{array}$ \\
\hline
\end{tabular}


ORR LATTICE LOADING

For Fuel Cycles 131-A, B

\begin{tabular}{l|c|c|c|c|c|c|c|c|c|}
\multicolumn{2}{c}{ I } \\
\cline { 2 - 7 }
\end{tabular}

LATTICE COMPONENT

Fue 1

Shim Rod (SR)

Beryllium (Be)

Experiment (E)

Iodine Sleeve $\left({ }^{131} I\right)$

Isotope Stringer (Iso)

Hydraulic Tube (HT)
NUMBER

$-27$

6

23

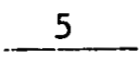

1

0

1

Figure 3. ORR Lattice Configuration - April 1, 1976 through April 21, $1976^{\circ}$ 
ORR LATTICE LOADING

For Fuel Cycles $131-C, D, F, F$

\begin{tabular}{|c|c|c|c|c|c|c|c|c|}
\hline 1 & 2 & 3 & 4 & 5 & 6 & 7. & 8 & 9 \\
\hline $\mathrm{Be}$ & $\mathrm{Be}$ & $I^{131}$ & F & $\mathbf{F}$ & F & $\mathbf{F}$ & $\mathrm{F}$ & $\mathrm{Be}$ \\
\hline $\mathrm{Bc}$ & $\mathrm{Bc}$ & $\mathbf{F}$ & SR & $\mathbf{F}$ & SR & F & E & $\mathrm{Be}$ \\
\hline $\mathrm{Be}$ & $\mathrm{Be}$ & $F$ & F & $F$ & F & $\mathbf{F}$ & F & $\mathrm{Be}$ \\
\hline $\mathrm{Be}$ & F & F & SR & $F$ & SR & F & $\mathrm{HT}$ & $\mathrm{Be}$ \\
\hline $\mathrm{Be}$ & $\mathbf{F}$ & $\mathbf{E}$ & $\mathbf{F}$ & $E$ & $\mathrm{~F}$ & $\mathrm{E}$ & F & $\mathrm{Be}$ \\
\hline $\mathrm{Be}$ & F & $F$ & SR & F & SR & $\mathbf{F}$ & $F$ & $\mathrm{Be}$ \\
\hline $\mathrm{Be}$ & $\mathrm{Be}$ & $\mathrm{Be}$ & $\mathrm{Be}$ & Be & $\mathrm{Be}$ & $\mathrm{Be}$ & $\mathrm{Be}$ & $\mathrm{Be}$ \\
\hline
\end{tabular}

LATTICE COMPONENT

ruel

Shim Rod (SR)

Reryl11um (Re)

Experiment (E)

Iodine Sleeve $\left({ }^{131} \mathrm{I}\right)$

Tsotopr. Stringer (Iso)

Hydraultc Tube (HT)
NUMBER

27

$-6$

24

4

$-1$

0

$-1$

Figure 4. ORR Lattice Configuration - Apri1 21, 1976 through May 22, 1976 
ORR LATTICE LOADING

For Fue1 Cycles 132-A, B

\begin{tabular}{|c|c|c|c|c|c|c|c|c|}
\hline 1 & 2 & 3 & 4 & 5 & 6 & 7 & 8 & 9 \\
\hline $\mathrm{Be}$ & $\mathrm{Be}$ & $I^{131}$ & $\mathbf{F}$ & $\mathbf{F}$ & $\mathbf{F}$ & $\mathbf{F}$ & F & $\mathrm{Be}$ \\
\hline $\mathrm{Be}$ & $\mathrm{Be}$ & $\mathbf{F}$ & SR & $\mathbf{F}$ & SR & $F$ & E & $\mathrm{Be}$ \\
\hline $\mathrm{Be}$ & $\mathrm{Be}$ & $\mathbf{F}$ & $F$ & $\mathrm{~F}$ & $F$ & $\mathrm{~F}^{\bullet}$ & F & $\mathrm{Be}$ \\
\hline $\mathrm{Be}$ & F & $F$ & SR & $\mathbf{F}$ & SR & $\mathbf{F}$ & HT & $\mathrm{Be}$ \\
\hline $\mathrm{Be}$ & $F$ & $\mathrm{E}$ & $F$ & F & $\mathrm{F}$ & $E$ & $\mathbf{F}$ & $\mathrm{Be}$ \\
\hline $\mathrm{Be}$ & $\mathrm{F}$ & $F$ & $\mathrm{SR}$ & $F$ & SR & $F$ & F & $\mathrm{Be}$ \\
\hline $\mathrm{Be}$ & $\mathrm{Be}$ & $\mathrm{Be}$ & $\mathrm{Be}$ & $\mathrm{Be}$ & $\mathrm{Be}$ & $\mathrm{Be}$ & $\mathrm{Be}$ & $\mathrm{Be}$ \\
\hline
\end{tabular}

LATTICE COMPONENT

Fue1

Shim Rod (SR)

Beryllium (Be)

Experinent (E)

Iodine Sleeve $\left({ }^{131} \mathrm{I}\right)$

Isotope Stringer (Iso)

Hydraulic Tube (HT)
NUMBER

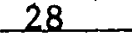

6

24

3

1

0

1

Figure 5. ORR Lattice Configuration - May 27, 1976 through June 21, 1976 


\section{THIS PAGE}

\section{WAS INTENTIONALLY LEFT BLANK}


ORNL/ TM-5698

\section{INTERNAL DISTRIBUTION}

1. R. G. Affel
2. M. A. Baker
3. F. T. Binford
4. R. K. Branam
5. C. D. Cagle
6. W. R. Casto
7. G. H. Coleman
8. J. A. Conlin
9. J. A. Cox
10. F. L. Culler
11. S. J. Ditto
12. B. C. Duggins
13. W. A. Duggins
14. C. B. Gaither
15. E. D. Gupton
16. T. P. Hamrick
17. V. O. Haynes
18. S. S. Hurt, III
19. L. P. Jernigan
20. E. B. Johnson
21. F. B. K. Kam
22. S. I. Kaplan
23. O. L. Keller
24. E. M. K1ng

25. Eugene Lamb

26. E. D. Lance

27. L. C. Lasher

28. R. V. McCord

29. F. H. Neill

30. T. B. Nixon

31. L. C. Oakes

32. Herman Postma

33. M. E. Ramsey

34. J. B. Ruble

35. T. M. Sims

36. M. J. Skinner

37. J. H. Swanks

38. J. R. Thomas

39. W. E. Thomas

40. K. R. Thoms

41. J. R. We1r, Jr.

42. K. W. West

43. E. J. Witkowski

44-46. Laborator Records Department

47. Laboratory Records, ORNL R.C.

48-49. Central Research Library

50. Document Reference Station

\section{EXTERNAL DISTRIBUTION}

51. K. M. Akhtar, Pakistan

52. Richard Brown-Campos, Puerto Rico

53-54. M. B. Biles, ERDA $\dot{j}^{\prime}$ Washington

55. Eric Blomber, Sweden

56. K. J. BobIn, Belgium

57. ERDA-ORO: Safety and Environmental Control Division

58. C. Moller, Repub1ic of South Africa

59. Director, Reactor Division, ERDA-ORO

60. Kiyoshi Inoue, Hitach1, Japan

61. M. Jacequemain, France

62. Masanori Kanbara, JAERI, Japan

63. W. Krull, West German Federal Republic

64. Research and Technical Support Division, ERDA-ORO

65. O. D. Oner, Turkey

66. G. Rada, Venezuela

67. R. J. Swaneburg de Veye, The Netherlands

68-94. Technical Information Center, Oak Ridge

95. R. Wakabayashi, NAIG, Japan

96. K. E. Wirtz, Germany

97. A. C. Woods, Australla 